\title{
Public History and the Odyssey of a Born-Again Native
}

\author{
REBECCA CONARD
}

LIKE MANY OTHER NATIVE IOWANS, I grew up on a farm - in my case, a quarter-section of undulating terrain in northwest Iowa that supported a modest dairy operation. Even though we were a tenant farm family, my dad belonged to a soil conservation district and practiced the kind of diversified farming that went out of fashion in the 1960s but is now slowly being reclaimed by sustainable agriculturists. On the far side of the farm, a fallen cottonwood provided a convenient sitting spot. The cows often were pastured near there in spring and summer, and I never tired of walking the path to fetch the herd for milking because it meant that I could steal a few minutes to hop up on the trunk, soak in the warmth of the day, and watch whatever crossed the horizon.

It is axiomatic that we are all shaped to some degree by environment in the literal sense of "place" as well as the figurative sense of "the times and circumstances," and self-evident truths are, by definition, hard to parse. As I began to think about the ways that growing up in Iowa has shaped my work as a historian, it became clearer that the figurative sense-the happenstance of being born on the leading edge of the baby boom gen-

Rebecca Conard is professor of history and public history at Middle Tennessee State University. Before entering teaching full time in 1992, she cofounded PHR Associates of Santa Barbara, California, a historical research consulting firm, and since 1993 she has been associated with Tallgrass Historians L.C. of Iowa City. She is a past president of the National Council on Public History.

THE ANNALS OF IOWA 67 (Spring-Summer 2008). (C) The State Historical Society of Iowa, 2008. 
eration - has been, on balance, a more powerful influence than place. The only childhood stories I can remember are my father's recounting of World War II experiences during the North African and Italian campaigns, and I have aged in lock step with the modern civil rights, feminist, and environmental movements. The truth is that, during my formative years, I developed no particular attachment to any place, except perhaps that dead cottonwood and my maternal grandmother's house in Ida Grove: the coo of a mourning dove will recall the feel of cool summer breezes at her kitchen window, and the scent of lilacs will rock my thoughts to the glider that sat under an immense lilac bush in the side yard. Those cherished memories notwithstanding, it was only as an adult that I began to explore Iowa in the course of "doing" public history. The repeated experience of connecting history with specific places and people, and learning to observe the landscape in historical, even geological, time, much like the process that Wes Jackson describes in Becoming Native to This Place, triggered a naturalizing effect of sorts. I am, if you will, a born-again native.

For better or worse, those of us who came of age in the 1960s carry the hard stamp of that decade. The televised 1960 Democratic National Convention was my rite of passage into political awareness - a classmate and I stayed up all night to watch Kennedy win the nomination-but even before then it was hard not to be aware of civil rights as a growing national crisis after the 1957 standoff at Little Rock's Central High. The fact that schools were battlegrounds in the fight for racial equality brought the issue to our level, but from the vantage point of my all-white, small-town high school, Lake View-Auburn, the discord was a distant and intermittent rumble. That changed in the summer of 1963, when I was tapped to be a student delegate to the Second Methodist Conference on Human Relations, which met in August, August 26-30 to be precise. Little in my rural Iowa upbringing had prepared me for that experience.

When I boarded the train for Chicago, I knew only that my destination was the Conrad Hilton Hotel and that the conference would address race relations; thus I was marginally prepared to join what turned out to be a biracial gathering of several hundred people. After the opening session, student delegates were 
escorted to a specially arranged meeting conducted by Student Non-violent Coordinating Committee recruiters. I was hardly a seasoned conference goer, but at that moment I knew this was no ordinary conference. During the next four days, the conference gradually turned into a civil rights rally even though the program included a fair number of obligatory discussions concerning the pending merger of Methodist denominations. There were animated discussions of racial issues in local communities, integrating local congregations, Martin Luther King Jr.'s letter from Birmingham City Jail (written just four months earlier), and the civil rights bill then before Congress. Speakers of national and international stature addressed "The Role of the Courts in Expanding Freedom," "Black Muslims - Challenge to the Church," and "The World Implications of Human Rights" issues that were largely beyond my ken at the time. James Meredith, Dick Gregory, and members of the Southern Christian Leadership Council took command of the auditorium for an afternoon. On Wednesday, August 28, the assembly joined hands and sang "We Shall Overcome" in solidarity with something called the Washington March, to which the conference sent six delegates. Only after the conference did I learn the magnitude and significance of that event.

It was an extraordinary experience, but then it was an extraordinary time. My personal encounter with the overwhelming power of the civil rights movement was, in the grand scheme of things, marginal but not inconsequential. Years later, reading Sara Evans's Personal Politics: The Roots of Women's Liberation in the Civil Rights Movement and the New Left (1979), I realized that I had observed firsthand a key strategy of the church-based movement: black and white clergy using the organized network of churches to spread the roots of citizen solidarity and, particularly, to reach into the hinterlands of the upper Midwest to recruit students for voter registration drives and other nonviolent action. That experience, and a similar horizon-expanding study tour of Washington, DC, and New York City during my senior year, occurred on a parallel plane with the normal activities of my teen years, which included youthful passions for music and vocal performance, but they are the indelible memories of my youth that travel in my day-to-day consciousness. 
Concerning the university years that eventually brought me to study history, I never actually made a decision about whether to go to college; I just knew that I would, even though neither of my parents had. In retrospect, I realize that I ended up on the college prep track largely because of Cold War-inspired changes in public education. The faults of that regime notwithstanding, I benefited from Iowa's public education system, the finest in the nation in the 1960s. Even at Lake View-Auburn High, consolidated but still small, I fell into the orbit of dedicated, talented, and creative teachers, especially three outstanding women who also were raising families and involved in community affairs. ${ }^{1} \mathrm{I}$ came of age at a time when girls on the college track still were expected to choose teaching or nursing; thus career counseling was not a priority. So, even though teaching then had no career appeal for me, I unconsciously adopted these three teachers as role models. Years later, as I was reordering personal priorities and making career choices, I appreciated them even more. They had been "doing it all" long before Betty Friedan published The Feminine Mystique and reinvigorated the feminist movement.

In adopting the term "born-again native" for this essay, I intentionally background the many years I have spent living elsewhere, including more than two decades in California. It is of some interest, however, to note that Frank Mitchell, another essayist in this issue, left the Midwest to pursue an academic career at the University of Southern California at roughly the same time I was drawn to southern California to pursue a college education. On some level, both of our experiences reflect the allure of the West that still figures prominently in western Iowa culture vis-à-vis John Buenker's experience growing up in the "state of Dubuque" and absorbing its stronger cultural affin-

1. Evonne Deur, whose approach to teaching drama included strategies such as taking a group of thespians to the newly opened (and now, sadly, gone) Tyrone Guthrie Theatre in Minneapolis to see Hume Cronyn in Moliere's The Miser; Arline Hunter, French and music, who drew on her experience as a performer to create a music program that rivaled the athletic program; and author Annabelle Irwin, composition and literature, who taught my generation how to write (and write and write) before she went on to teach writing at Iowa State University. Consolidation is an ongoing process among rural school districts; Lake View Auburn expanded to Wall Lake View Auburn, and in 2007 became East Sac County School District. 
ity with Chicago and points east. The M \& M divide of Iowa's topography, which sends some river waters to the Mississippi and some to the Missouri, permeates Iowa culture, too.

In any case, in 1976, having completed a graduate degree in folklore studies at UCLA, I thought I needed an interlude to contemplate the next big step. Admission to two doctoral programs lay on the table, neither option beckoning, so I retreated to a familiar place: home, Iowa. At the suggestion of one of those high school teachers I considered a mentor of sorts, I called Peter Harstad, then director of the State Historical Society of Iowa (SHSI), and asked if he had any special projects that might keep me busy for a summer. He did. My project was to conduct exploratory interviews with a small number of Century Farm owners in order to lay the groundwork for a larger oral history project. With a bit of fieldwork and oral history experience in my graduate studies, I was comfortable undertaking the assignment and quickly discovered that the people I interviewed considered me an insider because I had grown up on a farm.

The summer, however, turned out not to be the quiet interlude I was seeking. In one sense, it was a grand summer because I began learning Iowa's twentieth-century agricultural history inside out, from which vantage point I began to think about the forces that shape human uses of land over time and, more particularly, began to understand the outside forces at work during my father's time as a farmer, and his father's before him. Born in Germany, my paternal grandfather immigrated to the U.S. in the 1890s with his parents, who settled in the German enclave of Schleswig. In 1919, at the tail end of wardriven prosperity, he and my grandmother purchased a farm near Ida Grove, only to lose it during the Great Depression. In another sense, it was a summer of deepest sadness: my youngest brother sustained fatal injuries in a freak vehicular accident. The experience of connecting to the past through people who shared many details of their family history intertwined with the experience of waiting helplessly while a young life ended in a hospital operating room. I still have no words to adequately express that summer's force majeure except to note that because I felt powerless to protect my brother from death, I surrendered a piece of my heart to the earth of his gravesite. It was the be- 


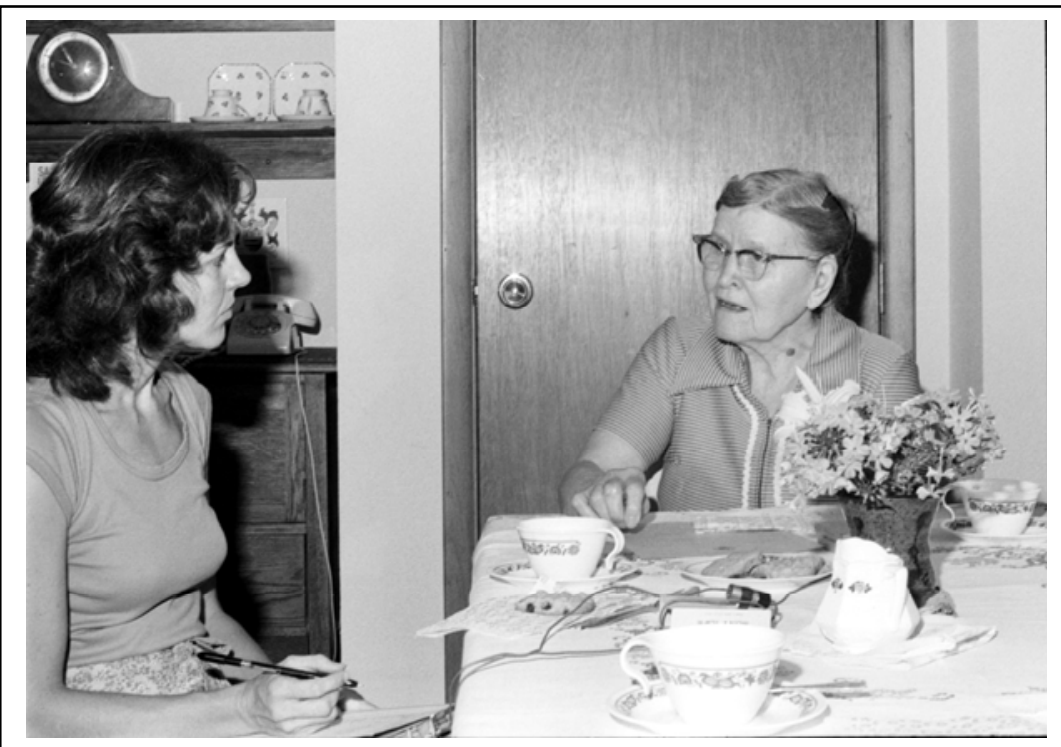

The author (left) interviews Rachel Hodgin for the Earthwatch-SHSI Oral History Project. Photo from State Historical Society of Iowa, Iowa City.

ginning of reconnecting with Iowa soil and my own family. In between interviewing Century Farm families, I spent many hours with my maternal grandmother recording her life story and family history, one that weaves back through the major strands of westward migration to four brothers sent to the colonies as soldiers in the British army during the revolutionary war who decided to take their chances in America after the fighting was over.

Sometimes the most amazing thing about life is the way mundane details carry us along. I returned to California at the end of the summer to accept a teaching position at American River Community College in Sacramento, which turned out to be the real interlude. During the next two years, a new routine filled my days as I made plans to return to Iowa in 1978 to continue the oral history project, this time with a field crew. ${ }^{2}$ The planning process entailed articulating the purpose for such an undertaking and the possible research value that might come

2. Oral history interviews of the Earthwatch-SHSI Oral History Project $[\mathrm{OH}$ 4], July-August 1978, State Historical Society of Iowa, Iowa City. 
from it. Initially, the intent had been to gather information about rural traditions among families whose roots in Iowa extended back at least two or three generations. But the pilot study revealed good potential for eliciting discussions about changes in land use across generations and the future of family farming. In due time, I found myself increasingly drawn to the study of history because it offered Context with a capital Cnot theories to guide analysis or intellectual constructs to discern patterns and shades of meaning, but a synthetic approach to understanding change over time, the forces great and small that affect human action, and the relevance of the past in contemporary society. The summer of 1976 had left me wondering about the meaning of life, and above all else I was seeking assurance that life had meaning. To make a long story short, the summer of 1978 confirmed my decision to jump disciplines, and in September I plunged into doctoral work in public history at U.C. Santa Barbara.

The decades since have been a public history odyssey. Professionally, one calls this a career, but it has always seemed more like a journey to me. During the past two decades especially, the journey has taken me to many out-of-the-way places in my native state and instilled a sense of place over time that comes only by getting to know the territory.

In the late 1980s, Ralph Christian, architectural historian in Iowa's State Historic Preservation Office (SHPO), talked me into taking on the daunting task of surveying Iowa's railroad architecture, a task accomplished only with the aid of a dedicated research assistant and a railroad buff whose detailed knowledge of extant railroad structures was unparalleled. The process of studying hundreds of remaining structures, together with documentary and field evidence of long-gone structures along the more than 10,000 miles of track that once crisscrossed Iowa, gave me an on-the-ground understanding of railroads as complex corporate organizations. Historians often cite railroads as the beginning of the modern corporate system of business, but we do not often stop to think about what that meant in physical, functional terms: what it took to move trains, passengers, and freight from one location to another; the infrastructure that supported long transportation routes; how railroads man- 
aged a labor force that was in constant motion and strung out in lines across vast distances. Roger Grant's work on railroads in Iowa helped me reconceptualize railroad architecture in functional rather than stylistic terms. ${ }^{3}$ That, in turn, opened me to thinking about how historians contextualize the particulars of local history. ${ }^{4}$

Scholars have, for instance, profiled the major rail lines, insofar as corporate records allow, and examined the ways railroads enabled the rapid extraction of natural resources to industrialize cities and whole regions, shifted the north-south axis of river commerce to the horizontal axis of rail transport, and decentralized the meatpacking industry. Juxtaposed with such big-picture views, local history often seems insignificant. But if one shifts the vantage point to draw connections from specifics to meaningful patterns or universals, as evaluating the significance of historic places requires one to do, the past becomes more complex and new questions arise. For example, how did local merchants and manufacturers use Iowa's intricate rail network to expand markets to levels sustainable with local labor pools? Or, how did that intricate network contribute to shaping and reshaping the social and cultural contours of Iowa over time? Understandably, historic preservationists and local communities across Iowa have focused on saving depots and adapting them to new uses. In exchange, we have lost roundhouses where mechanics serviced train engines; freight warehouses where dock workers transferred cargo; shops where carpenters, blacksmiths, and other skilled workers built and maintained the infrastructure; and all the other functionally specific structures - water tanks, coal chutes, sand bins, and firehouses - needed

3. Grant's publications in railroad history constitute a lengthy list, but much of his work focuses on railroads in small towns and rural areas. Especially useful for the Iowa railroad architecture study was The Country Railroad Station in America (Sioux Falls, SD, 1988), which he coauthored with Charles W. Bohi.

4. Rebecca Conard, "Once I Built a Railroad: Viewing Railroad History from the Depot Platform," Public Historian 14 (1992), was an early attempt to examine what happens in the research process when one begins by asking questions that arise in the course of observing historic structures in situ. The most straightforward and basic question - "Why is this structure located in this place?" - can spur one to investigate sources that might not otherwise be obvious. 
to operate railroad systems in the days of steam locomotion. Less than three decades after my 1963 train trip to Chicago, still a normal way to travel long-distance at the time, most of the rails that made that trip possible were gone. The depots, few of them even located adjacent to an active line, stand as icons of the industrial age on the prairie, their meaning more felt than understood.

A couple of years later, I worked with historian Lowell Soike, also with the Iowa SHPO, on a statewide survey of historic places associated with the conservation movement. Not only did the project align with my interests in environmental and modern U.S. history, but the fieldwork put me in touch with the Iowa landscape in ways that I had not experienced since childhood, whether it was boating to an island in the Mississippi River to document early fish-rearing ponds, following a ridgeline to document a 1930s watershed protection project in southwest Iowa, or stretching out in Hayden Prairie Preserve on a hot summer afternoon to be enveloped by a cool mixture of grass, breeze, and earth.

The research also took me into the history of progressivism in Iowa, still a rich field for scholars. Perhaps the most visible legacy of progressivism and the conservation movement in Iowa is the state park system. The voices of those who articulated the need for creating Iowa's system of parks and preserves were botanists, geologists, ornithologists, natural scientists, and nonprofessional naturalists who were documenting the decline or degradation of Iowa's timberlands, native prairies, songbirds, fish and game populations, sovereign lakes, rivers, and water quality. The resource concerns of early twentieth-century natural scientists such as Thomas Macbride, Louis Pammel, Ada Hayden, and others resonated so clearly with contemporary environmental concerns that I was drawn to study the relationship between the park movement and environmentalism in Iowa in some depth, work that resulted in Places of Quiet Beauty: Parks, Preserves, and Environmentalism (1996). When the title became the slogan for the 75th anniversary of state parks, I took it as the sincerest form of flattery: a cap emblazoned "Places of Quiet Beauty: State Parks 1997" hangs in my study. 
In a twist of fate, Iowa history brought me to a deeper understanding of my chosen profession, public history, not only through professional practice and association with other Iowans working in the field, but also by studying one of the true pioneers of public history. Benjamin Shambaugh, the State Historical Society of Iowa's first director, devoted much of his career to developing an intellectual rationale for the practice of history in the wider world. An academician himself, inasmuch as he also served as the founding director of the political science department at the University of Iowa, he nonetheless envisioned a dynamic role for history in service to the commonwealth. Shambaugh articulated his vision most clearly in a set of policy studies that he called the Applied History Series, but his legacy also includes one of the most complete state studies of homefront activity during World War I, the founding of one of the earliest popular history magazines, still published under the title Iowa Heritage Illustrated, and the pathbreaking Commonwealth Conferences of the 1920s. Mary Bennett, curator of special collections at the State Historical Society of Iowa's Iowa City library, convinced me to turn an unpublished biography of Shambaugh into a more nuanced study that situates him in the context of progressivism and disciplinary professionalization during the late nineteenth and early twentieth centuries. Writing Benjamin Shambaugh and the Intellectual Foundations of Public History (2002) caused me to rethink everything I thought I knew about the history of the profession and to look more closely at the influence of scientific thought and progressive reform movements on the practice of history. That, in turn, changed my approach to teaching public history, which is what I do most of the time, and cultivated a new research interest in the historiography of historical practice.

Several public history projects have allowed me to explore the territory that is most familiar to me-northwest Iowa-and, in the process, I have acquired a deep appreciation for local history. Surveys of historic structures in Lake City and Sac City, two of several communities I have come to know better, revealed not only the patterns of community development over time but also the ways rural areas have been idiosyncratically connected to widespread trends and national events-and 
sometimes oddly disconnected from broader influences. Lake City's growth, for instance, rested in large part on its status as a division point for the Chicago \& North Western Railroad. Sac City, however, rejected an 1859 proposal to subsidize local railroad construction, but its county seat status enabled the town to survive, even prosper to a degree. Nonetheless, when the Chicago \& North Western extended rail service to Sac City in 1879, the pace of growth accelerated, helping to sustain a period of economic prosperity that lasted through World War I, a period that often is called Iowa's Golden Age. In both towns the housing stock steadily increased and new businesses persisted until the 1920s, suggesting that the forces of growth were robust enough to mitigate, or at least soften, ripple effects of the 1873 and 1893 economic depressions. Community studies of this nature do not adequately document patterns of agricultural development and economics in the surrounding rural areas, but they nonetheless correlate with the findings of economic and political historians who have sought to explain why the Populist Party was relatively weak in Iowa.

Sometimes the fine texture of history leads, even forces, one to ask different questions about the past. Lake City is known to most Iowans as the "lake" city without a lake, but in the surrounding area it has a long-standing identity as a regional medical center, a curious circumstance because the town ceded its status as a county seat to Rockwell City early on, in 1876, and its population has remained static since the 1920s. In a different vein, what motivated citizens of Sac City to erect not one, but two, monuments commemorating the "War of the Rebellion"?5 Unraveling the past in search of plausible explanations for the anomalies as well as patterns of material culture is often the path to situating local history in new contexts or finding thematic connections. Lake City's function as a regional medical center may stem from its designation as a railroad division

5. "War of the Rebellion" is the name for the Civil War found on many northern monuments. In the South, counterpart names are the "War for Southern Independence," popular during the war, and the "War of Northern Aggression," which came into use during Reconstruction as the Lost Cause movement took hold. In the 1890s, "War Between the States" became the unofficial neutral term as North and South began to reconcile. 
point, which, among other things, meant locating a physician in town to attend to the medical needs of railroad workers, a semitransient workforce. Whatever the genesis, no fewer than 16 physicians were practicing in Lake City by the early 1900s. The specific actors and precise motives of Sac Citians who were inspired to erect two Civil War monuments may not have been recorded. Nonetheless, the facts that they appear in a place so remote from the theaters of war and that one of them sits adjacent to a Grand Army of the Republic meeting hall attest to how deeply sectional politics were ingrained in rural Iowa culture. They also suggest the degree to which northerners were complicit in silencing the underlying issue of slavery that caused four years of fierce, bloody warfare.

Perhaps the most persistent question of local history is what distinguishes one town from another. National media have stereotyped Iowa as the most homogenous state. Never mind reality; to outsiders, the state is flat and one place looks pretty much like another. But no two places are alike, and the question of community identity has taken on considerable import in an era when far too many Iowa towns are trying to stimulate economic growth and stem population loss. In the search for winning strategies, heritage tourism has been widely embraced for its potential to bolster local coffers, although it takes more than a marketable past to transform a place into a destination. However, if community development, that is, injecting dollars into the local economy, is the underlying motive for historic preservation planning, as it often is, the goal of identifying historic sites and structures that embody a community's distinctive past becomes more critical, and often political. Despite at least four decades of scholarship that approach community studies through history, anthropology, sociology, and economics, a perceived relationship between shared community identity and community vitality remains more believed than understood. Perhaps this is the fascination as well as the frustration of local history. In any case, my experiences working with Iowa communities on preservation-based studies in the role of a professional historian who is also a hybrid insider-outsider has led me to respect the interpersonal dynamics of collaborative inquiry and the agency of local history keepers. When one is accepted 
as an insider, dismissing local politics as bothersome or treating local history as quaint is not an option.

As historian Lucy Salmon pointed out nearly a century ago, there is always "History in a Back Yard." 6 My odyssey with public history has brought me to see the identity of my own hometown, Lake View (not to be confused with nearby Lake City), from a new perspective. I grew up taking for granted our two lakes, Black Hawk and Arrowhead, and all the park and protected areas adjacent to them, but parks do not simply emerge from the landscape. The progressivism that gave Iowa its state park system also gave rise to an era of local-state collaboration in the cultural context of "pluralism" that George McJimsey discusses in his essay. ${ }^{7}$

When the newly created Iowa Board of Conservation (now Department of Natural Resources) assumed responsibility for managing the state's natural lakes, they were in various states of degradation after decades of neglect and encroachment from farming and livestock grazing. In Iowa as elsewhere land acquisition to make lake management possible was a contentious process. Even so, the Board of Conservation found willing collaborators among the local Izaak Walton League chapter, which served as the unofficial caretaker for Black Hawk Lake (called Wall Lake until 1934), and a private landowner who, in 1920, dedicated a strip of land along the lakeshore for public use. That prompted the city to create a park commission and purchase enough residential lots to create a lakeside park, subsequently landscaped with assistance from Iowa State College Extension Service. In the late 1920s the city took another big step and donated to the state 150 acres of eroded land containing an abandoned gravel pit. Women of the local chapter of the Daughters of the American Revolution stepped forward to assist the Board of Conservation by planting a stand of trees around the water-filled gravel pit, christened Lake Arrowhead,

6. Lucy Salmon, "History in a Back Yard" (1912), reprinted in History and the Texture of Modern Life: Selected Essays, ed. Nicholas Adams and Bonnie G. Smith (Philadelphia, 2001).

7. See also George McJimsey, Harry Hopkins: Ally of the Poor and Defender of Democracy (Cambridge, MA, 1987); and idem, The Presidency of Franklin Delano Roosevelt (Lawrence, KS, 2000). 
all of which gradually became habitat for wildlife in a designated game refuge.

Throughout the 1920s, local organizations, individuals, and the town council worked in loose coalition with one another and with the state to approach land acquisition and park development from different angles. Thus, when federal funds for resource conservation and park development became available through New Deal programs in the 1930s, the groundwork had been laid for another collaborative effort to fully develop a state park. With federal relief aid to pay for labor and technical assistance, the state and the city erected a number of stone park structures. As a result, in less than two decades, approximately onehalf of the lakeshore frontage was transformed into public open space with designated outdoor recreation areas that invited picnicking, hiking, swimming, fishing, boating, and hunting.

The dedication of Black Hawk Lake State Park on Labor Day 1934, along with a cast stone statue of its eponymous Sauk warrior, marked the emergence of a new public image that drew on the town's enhanced association with two lakes and public open space. At the time, no one foresaw the huge demand for outdoor recreation that would emerge after World War II. But, with ample recreation resources available for use, Lake View's economic base gradually began to shift in the 1950s from agriculture to a broader base of agriculture and outdoor recreation. As a result, the community was better positioned to weather the 1980s downturn in the farm economy. Today, few residents take the lakes and parks for granted. Reshaping the town's physical relationship with its natural environment also reshaped local attitudes about the related values of outdoor recreation and resource conservation. Hence, in the 1990s the community supported and once again collaborated with state and federal agencies to clean up Black Hawk Lake and restore the now historic stone park structures. Although working relationships have often been strained and collaboration sometimes forced, there is an elegant simplicity about the stone park structures, now listed on the National Register of Historic Places. In their own quiet way, naturalized into the landscape, they represent a remarkably complex chapter of interwoven local, state, and national history. 


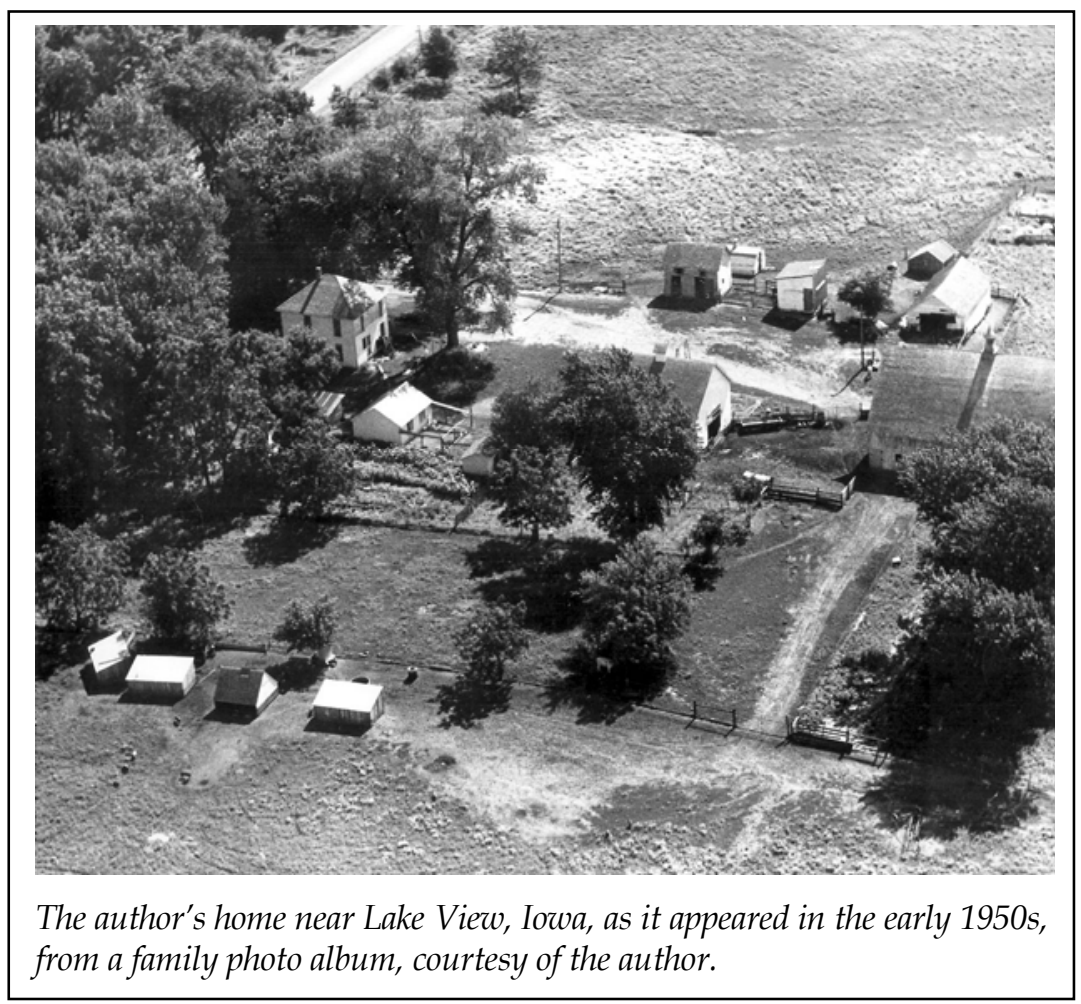

My family left the farm in December 1963 and moved to town. Shortly thereafter I went off to college and another long chapter of life in California. But during the late 1980s and early 1990s, as I was relearning native territory, I drove past the farm occasionally, watching the smaller outbuildings disappear one by one, then the big barn, and, finally, the house itself, leaving only an aged cottonwood tree, which, ironically, my mother was certain would fall in some storm and smash the house-an uninsulated four-square in which the icy bloom of rime-etched windowpanes defined the winter season. Watching the farmstead disappear over a period of years was akin to watching my personal past slowly be erased. But by the time everything had disappeared except the cottonwood standing sentry over the ghost of my childhood, a different landscape of Iowa had taken shape in my mind's eye-a layered landscape, far more varied and vastly more interesting than the familiar local landmarks 
by which we all navigate home turf and the iconic landmarks with which travelers associate Iowa. While I wish that more old farmsteads were still standing along the graveled grid of rural Iowa, I enjoy watching the emergence of fields of wind turbines harvesting the prairie wind. While I wish that every small town still had a vibrant main street, I admire every community that harnesses local energy and talent to preserve historic places. And while I wish that Iowans had a stronger commitment to land stewardship, I am deeply grateful for the farsighted individuals who worked to preserve bits and pieces of what Iowa was like when it was the land of the Sauk, Meskwaki, and Sioux, and before them the Oneota, Woodland-Hopewell, and PaleoIndian cultures. 